Review

\title{
Fetal Hemoglobin in Sickle Hemoglobinopathies: High HbF Genotypes and Phenotypes
}

\author{
Martin H. Steinberg \\ Department of Medicine, Division of Hematology/Oncology, Center of Excellence for Sickle Cell Disease, \\ Center for Regenerative Medicine, Genome Science Institute, Boston University School of Medicine and Boston \\ Medical Center, 72 E. Concord St., Boston, MA 02118, USA; mhsteinb@bu.edu
}

Received: 3 November 2020; Accepted: 19 November 2020; Published: 23 November 2020

\begin{abstract}
Fetal hemoglobin $(\mathrm{HbF})$ usually consists of 4 to $10 \%$ of total hemoglobin in adults of African descent with sickle cell anemia. Rarely, their $\mathrm{HbF}$ levels reach more than $30 \%$. High $\mathrm{HbF}$ levels are sometimes a result of $\beta$-globin gene deletions or point mutations in the promoters of the $\mathrm{HbF}$ genes. Collectively, the phenotype caused by these mutations is called hereditary persistence of fetal hemoglobin, or HPFH. The pancellularity of $\mathrm{HbF}$ associated with these mutations inhibits sickle hemoglobin polymerization in most sickle erythrocytes so that these patients usually have inconsequential hemolysis and few, if any, vasoocclusive complications. Unusually high $\mathrm{HbF}$ can also be associated with variants of the major repressors of the $H b F$ genes, $B C L 11 A$ and $M Y B$. Perhaps most often, we lack an explanation for very high $\mathrm{HbF}$ levels in sickle cell anemia.
\end{abstract}

Keywords: hereditary persistence of fetal hemoglobin; gamma-globin gene; gene deletion; globin gene expression; genotype/phenotype

\section{Fetal Hemoglobin Levels in Sickle Cell Anemia}

Fetal hemoglobin (HbF; $\left.\alpha_{2} \gamma_{2}\right)$, encoded by two nearly identical $\gamma$-globin genes (HBG2, HBG1) that are part of the $\beta$-globin gene (HBB) cluster (11p15.4), comprises 70 to $90 \%$ of the hemolysate in newborns, falling to $<1 \%$ after 12 months [1]. The "switch" from fetal to adult hemoglobin synthesis in sickle cell anemia (homozygosity for the sickle hemoglobin gene) takes 5 to 10 years and is rarely complete. The sickle hemoglobin gene $(\mathrm{HbS})$ is found on five common genetic backgrounds, or haplotypes. Patients of African descent have Bantu, Benin, Cameroon or Senegal haplotypes; in most of these patients a stable $\mathrm{HbF}$ level of $\sim 4$ to $10 \%$ is reached at $\sim 5$ years of age. In individuals of Middle Eastern or Indian extract with the Arab-Indian haplotype, stable $\mathrm{HbF}$ levels of $\sim 17 \%$ are achieved at 10 years of age [2,3]. Sometimes, in treatment-naive adults of African descent $\mathrm{HbF}$ levels between 15 and 30\% are present; this can be accompanied by mild disease [4]. Patients with the Arab-Indian haplotype can have $\mathrm{HbF}$ far above $20 \%$, but no informative genetic studies of the very high $\mathrm{HbF}$ phenotype have been done in this population; the following sections deal only with patients of African ancestry [5]. Among the causes of unusually high $\mathrm{HbF}$ levels are deletions or single base substitutions in the $H B B$ gene cluster and single nucleotide polymorphisms (SNPs) in the genes $B C L 11 A$ and $M Y B$ that encode repressors of $H b F$ gene expression. This review focuses on the genetic basis and clinical implications of unusually high $\mathrm{HbF}$ levels in sickle cell anemia patients of African descent. Comprehensive reviews discuss more general aspects of $\mathrm{HbF}$ in sickle cell anemia [6-11]. It is worth remembering that newborn screening for sickle cell anemia by fractionation of the hemoglobin proteins cannot distinguish amongst causes of the very high $\mathrm{HbF}$ phenotypes. This requires clinical follow-up, hematologic studies, and, to understand the molecular basis of these phenotypes, detailed genetic studies. 


\section{Persistent High HbF: Mutations of the $\beta$-globin Gene Cluster}

\subsection{Hereditary Persistence of Fetal Hemoglobin and $\delta \beta$ Thalassemia}

Hereditary persistence of fetal hemoglobin, or HPFH, a term perhaps first coined in 1958, is defined by deletions or point mutations within the $H B B$ gene cluster [12]. Large deletions that result in higher than normal levels of $\mathrm{HbF}$ persisting into adulthood cause the most frequently recognized type of HPFH (Figure 1). $\delta \beta$ thalassemia is also caused by HBB gene cluster deletions but has some hematologic features of thalassemia. HPFH and $\delta \beta$ thalassemia are overlapping phenotypes; their distinction is historical and semantic. The sizes of the causative deletions overlap while their $5^{\prime}$ and $3^{\prime}$ breakpoints differ. Deletions of different sizes with diverse breakpoints might differentially change the interactions among $\gamma$-globin genes and their upstream and downstream regulatory elements, such as the locus control region (LCR), and transcription factor complexes. This could account for the wide variation in $\mathrm{HbF}$ levels in heterozygous carriers of these mutations and in compound heterozygotes with the $\mathrm{HbS}$ gene. Identical HPFH-causing mutations, can be associated with dissimilar $\mathrm{HbF}$ levels. Although the causes of this are unknown, this might be a result of the inheritance of the minor alleles of the quantitative trait loci (QTL) modulating $\mathrm{HbF}$ production that are associated with higher $\mathrm{HbF}$ and are discussed below. Reports of QTL genotypes in HPFH have not been published.

\section{A}

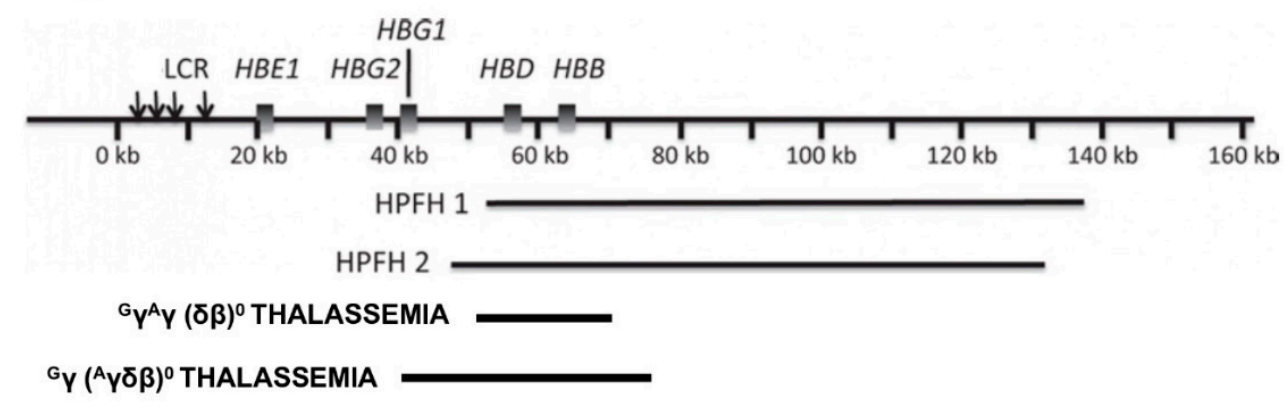

B

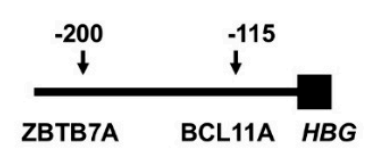

Figure 1. Deletions in the $H B B$ gene cluster associated with increased HbF. (A) Displayed are the genes in the $H B B$ gene cluster. The locus control region (LCR) that is upstream of $H B E$ forms contacts with the promoters of the genes in this cluster affecting their transcription. When $H B B$ and $H B D$ are deleted, interactions between the promoters of the $\gamma$-globin genes and the LCR are favored. Beneath the $H B B$ gene cluster are shown the locations and approximate sizes of common HPFH and $\delta \beta$ thalassemia deletions. (B) At positions -115 and -200 upstream of both $H B G 2$ and HBG1 are binding motifs for the $\gamma$-globin gene repressors, ZBTB7A at $-200 \mathrm{bp}$ and BCL11A at $-115 \mathrm{bp}$, respectively. Point mutations and small deletions in these regions and in nearby sites in the promoters, as detailed in Table 2, cause $\mathrm{HPFH}$ by altering the binding of these and other transcription factors.

Pancellular vs. heterocellular $\mathrm{HbF}$ distribution has been used as a defining aspect of HPFH. All erythroid precursors have the same mutation so that this distinction could simply be an artifact of the insensitivity of $\mathrm{HbF}$ measurement in individual erythrocytes. In pancellular $\mathrm{HPFH}$, whether measured either by fluorescence-activated cell sorting (FACS) or Betke staining, the concentration of $\mathrm{HbF}$ among F-cells, or cells containing measurable $\mathrm{HbF}$, is not homogeneous. In most studies $\sim 6 \mathrm{pg}$ of $\mathrm{HbF} /$ erythrocyte is required for the detection of an F-cell by the commonly used FACS assay. The pancellularity of $\mathrm{HbF}$ becomes obvious with $~ 30 \% \mathrm{HbF}$ in $\mathrm{HbS}-\mathrm{HPFH}$ where red cells can have an average of $10 \mathrm{pg}$ of $\mathrm{HbF} / \mathrm{F}$-cell, well above the limits of FACS detection. In HPFH due to HBG2/HBG1 promoter mutations where $\mathrm{HbF}$ levels can be $10 \%$ or less, pancellularity would result in 
$\mathrm{HbF}$ concentrations of 3 to $4 \mathrm{pg}$ of $\mathrm{HbF} / \mathrm{F}$-cell, a concentration well below the limits of FACS detection. Therefore, $\mathrm{HbF}$ appears pancellular when $\mathrm{HbF}$ levels are high and heterocellular when $\mathrm{HbF}$ is lower. Differences between pancellular and heterocellular HPFH is likely to reflect the magnitude of the increase in $H B G 2$ or HBG1 expression caused by HPFH mutations. Heterocellular HbF distribution might also be a result of epigenetic influences on gene expression leading to position-effect variegation, as proposed by Wood $[13,14]$. With this context, let us now consider the persistent high HbF caused by mutations in the $\beta$-globin gene cluster.

\subsection{HbS-Gene Deletion HPFH and $\delta \beta$ Thalassemia}

Deletions of about 85 kilobases that remove $H B B$ and $H B D$ account for the most commonly reported HPFH 1 and HPFH 2 mutations although many other HPFH deletions have been recognized [13]. In HPFH 1 and 2, HBG2 and HBG1 are preserved and $\mathrm{HbF}$ levels of $30 \%$ are present in heterozygotes; homozygotes have $100 \% \mathrm{HbF}$. Based on hematologic and electrophoretic findings, about $0.1 \%$ of African Americans were estimated to have the HPFH genotype; an estimation of 1 case in 14,000 was made from the Jamaican birth cohort [15-17]. The nearly uniform presence of mild microcytosis suggests that compensatory increase in $\gamma$-globin chain (HBG2/HBG1) production is nearly, but not totally, complete even though balanced $\alpha$ - to non- $\alpha$-globin synthesis has been found [18]. All erythrocytes contain some $\mathrm{HbF}$. This pancellular distribution was first pointed out by Conley in 1963, who attributed the benignity of $\mathrm{HbS}-\mathrm{HPFH}$ to this $\mathrm{HbF}$ distribution [16]. When $\mathrm{HbS}$ is present in compound heterozygosity with an $\mathrm{HPFH}$ deletion, $\mathrm{HbS}$ polymerization is inhibited in most erythrocytes resulting in nearly normal hematology; ${ }^{51} \mathrm{Cr}$ red cell half-life was normal (Table 1) [16,19]. A problem in understanding the phenotype of HbS-HPFH is that the hemoglobin genotypes are not always precisely defined. In the largest series of molecularly defined $\mathrm{HbS}-\mathrm{HPFH}$, where gap-PCR assays were designed specifically to detect HPFH 1 and HPFH 2, HbF was $31.3 \pm 2.4 \%$ in 30 cases aged $>5$ year [19].

The clinical phenotype, while usually referred to as "benign" is less definitively characterized than the hematologic phenotype because of the rarity of $\mathrm{HbS}-\mathrm{HPFH}$ and the lack of prospective case series with uniform and detailed clinical information. Additionally, most reported patients are young, there is a strong inverse relationship between $\mathrm{HbF}$ and age and certain complications of sickle cell disease are age-related [19]. Cases have been reported of osteonecrosis, joint pain, splenomegaly, splenic infarction, retinopathy and hemiparesis. In most instances the $H B B$ mutation was not characterized so the cause of the HPFH phenotype was undefined [16,20]. Of 13 adults with $\mathrm{HbF}>14 \%$, who were not taking hydroxyurea, which increases MCV and $\mathrm{HbF}$, one individual was deemed to have $\mathrm{HbS}-\mathrm{HPFH}$; she had painful episodes. This 25 -y-old woman had $\mathrm{HbF}$ of $28.5 \%$ that appeared pancellularly distributed; hemoglobin concentration was $11.7 \mathrm{~g} / \mathrm{dL}, \mathrm{LDH} 145 \mathrm{IU} / \mathrm{L}$ and bilirubin $0.6 \mathrm{mg} / \mathrm{dL}$. The MCV of $89.4 \mathrm{fL}$ was unusually high for the HbS-HPFH genotype. The molecular basis of HPFH was not described in detail [21]. Two patients with HbS-HPFH had a history of pain episodes and transfusion. Both had the Indian HPFH 3 that removes $48.5 \mathrm{~kb}$ of DNA, starting from the $5^{\prime}$ end of the $\psi \beta$ gene to a region $30 \mathrm{~kb}$ downstream of $H B B$ [22,23]. Their $\mathrm{HbF}$ was 27 and $29 \%$, hemoglobin 12.0 and $11.5 \mathrm{~g} / \mathrm{dL}$ and MCV 74.5 and $72.8 \mathrm{fL}$. Thirteen Brazilian children with HbS-HPFH were studied using gap-PCR, nine had HPFH 2 deletion and four had HPFH 1 . Hemoglobin concentration was $12.5 \pm 0.6 \mathrm{~g} / \mathrm{dL}$ with mild microcytosis and $\mathrm{HbF}$ was $42.3 \% \pm 2 \%$ (this $\mathrm{HbF}$ level, which is much higher than usually reported in $\mathrm{HbS}-\mathrm{HPFH}$, was quantified by alkaline electrophoresis that is not the preferred means of analysis). Acute chest syndrome and painful episodes occurred in four children; nine were asymptomatic; none had abnormal transcranial Doppler exams [24]. Splenic infarction was reported in an 18 year old man with HbS-HPFH 2 [25].

Hematologic and family studies of individuals with $\mathrm{HbF}$ levels $>20 \%$ were used to discriminate among 13 patients with $\mathrm{HbS}-\mathrm{HPFH}$, four with $\mathrm{HbS}-\beta^{0}$ thalassemia and 10 with sickle cell anemia [26]. $\mathrm{HbA}_{2}$ levels were high in HbS- $\beta^{0}$ thalassemia. Compared with sickle cell anemia, HbS-HPFH had higher $\mathrm{HbF}$ and hemoglobin concentrations; $\mathrm{MCV}$, reticulocyte counts and bilirubin levels were lower. Although the molecular basis of neither HPFH nor $\beta$ thalassemia was determined, in this and many 
other studies it is usually possible to ascertain the presence of HbS-deletion HPFH by a combination of $\mathrm{HbF}$ measurement, blood counts, erythrocyte indices and hemoglobin phenotyping in informative family members. While this is sufficient for patient management, DNA-based ascertainment of the hemoglobin genotype should be used if reproductive counseling is provided.

$\delta \beta$ thalassemia is also caused by different deletions in the $H B B$ gene cluster. These deletions remove $H B B, H B D$ and sometimes HBG1. In the latter case only HBG2 is present $\left({ }^{\mathrm{G}} \gamma\left({ }^{\mathrm{A}} \gamma \delta \beta\right)^{0}\right.$ thalassemia). HbS- $\delta \beta$ thalassemia deletions sparing both $\gamma$-globin genes $\left({ }^{\mathrm{G}} \gamma^{\mathrm{A}} \gamma(\delta \beta)^{0}\right.$ thalassemia) tend to be $10-20$ $\mathrm{kb}$ long compared with $\sim 85 \mathrm{~kb}$ in HPFH 1 and 2 [13]. Although ${ }^{\mathrm{G}} \gamma^{\mathrm{A}} \gamma(\delta \beta)^{0}$ thalassemia is a common cause of $\beta^{0}$ thalassemia in some Mediterranean populations, there are few well documented examples of compound heterozygosity with the $\mathrm{HbS}$ gene. In $\delta \beta$ thalassemia, $\mathrm{HbF}$ distribution is said to be heterocellular. The compensation for absent $\beta$-globin synthesis in $\delta \beta$ thalassemia is usually less complete than in the common HPFH deletions accounting for lower hemoglobin levels. The phenotype of $\mathrm{HbS}-\delta \beta$ thalassemia is difficult to define precisely but might be similar to that of HbS-HPFH.

\subsection{HbS-HPFH Due to Point Mutations}

This genotype, the result of many different mutations in the promoters of HBG2 and HBG1 and a single $\mathrm{C}>\mathrm{T}$ polymorphism in $H B G 2$, is associated with a diversity of $\mathrm{HbF}$ levels (Table 2). The point mutation can be in cis or in trans to the HbS gene [27]. Once referred to as heterocellular $\mathrm{HPFH}, \mathrm{HbF}$ can be distributed both pancellularly in cases where $\mathrm{HbF}$ levels are high or heterocellularly when $\mathrm{HbF}$ is lower, a likely reflection of the level of $H B G 2$ or $H B G 1$ expression [4]. Promoter mutations and the HBG2 polymorphism (rs7482144) increase $\mathrm{HbF}$ as a result of altered binding of the major $\mathrm{HbF}$ repressors, ZBTB7A and BCL11A, to their binding motifs and perhaps through the recruitment of other transcriptional activators like GATA1 to their nearby binding motifs. The most important $\mathrm{HbF}$ suppressor motifs lie $\sim 200$ and $\sim 115$ base-pairs upstream of the transcriptional start sites of each $\gamma$-globin gene and bind ZBTB7A and BCL11A, respectively (Table 2) [28,29]. Disruption of the HBG2 QTL 158 bps upstream of this gene and marked by rs7482144, increased HbF about half as much as disruption of the ZBTB7A and BCL11A binding motifs. Rs7482144 affects only HBG2, whereas both $\gamma$-globin genes are modulated by ZBTB7A and BCL11A, perhaps accounting for this difference [30,31]. The diversity of $\mathrm{HbF}$ levels associated with point mutations at the same nucleotide or adjacent nucleotides might be explained by how the physical interactions between the transcription factor and its binding motifs or interactions among the proteins in a transcription factor complex are perturbed.

Both a point mutation and rs7482144, the $-158 \mathrm{C}>\mathrm{T}$ polymorphism, can be in cis. This confluence could possibly account for the unusually high $\mathrm{HbF}$ in two $\mathrm{HbS}$ heterozygotes that had the $-158 \mathrm{C}>\mathrm{T}$ polymorphism and the $-175 \mathrm{~T}>\mathrm{C}$ mutation and had $\mathrm{HbF}$ of 27 and $41 \%$ [32,33]. The $\mathrm{C}>\mathrm{G}$ mutation $-202 \mathrm{bp}$ upstream of HBG2 was found in a man with HbSC disease who had a hemoglobin of $15.4 \mathrm{~g} / \mathrm{dL}$, MCV $86 \mathrm{fL}, 55 \% \mathrm{HbS}, 18 \% \mathrm{HbC}$ and $25 \% \mathrm{HbF}$. The mutation was presumed to be in cis to $\mathrm{HbC}$ [33].

Table 1. Hematologic findings in sickle cell disease with unusually high fetal hemoglobin (HbF).

\begin{tabular}{ccccc}
\hline & HbF (\%) & Hemoglobin (g/dL) & Reticulocytes (\%) & MCV (fL) \\
\hline HbS-HPFH $^{1}$ & 32.9 & 12.6 & 1.7 & 74.9 \\
HbS- $\delta \beta$ thalassemia $^{2}$ & $20-25$ & 11 & 2 & $75-90$ \\
QTL $^{3}$ & $\sim 15$ & 9 & - & $80-100$ \\
Promoter mutations & Highly variable HbF; few reports in sickle cell anemia (see Table 2) \\
\hline
\end{tabular}

${ }^{1}$ Hereditary persistence of fetal hemoglobin (HPFH) 1, 2, 3 defined by gap-PCR. Results are averages in 51 cases, not adjusted for age. HbF was measured by different methods. ${ }^{2}$ Few cases reported. ${ }^{3}$ Sickle hemoglobin gene (HbS) homozygotes with 1 to 4 minor alleles of the 3 known quantitative trait loci (QTL) that are associated with $\mathrm{HbF}$, as reported in [34]. 
Table 2. Point mutations in HBG2 and HBG1 promoters and the polymorphism in the HBG2 promoter that have been associated with increased $\mathrm{HbF}$ in heterozygotes and compound heterozygotes with $\mathrm{HbS}$. Approximate $\mathrm{HbF}$ levels are presented.

\begin{tabular}{|c|c|c|}
\hline Mutation & Gene & HbF (\%); Biology; Association with HbS \\
\hline$-567 \mathrm{~T}>\mathrm{G}$ & $H B G 2$ & 6-10: affects GATA and TAL1-binding motif \\
\hline$-4 \mathrm{bp}(-225 /-222)$ & HBG1 & 7 \\
\hline$-211 \mathrm{C}>\mathrm{T}$ & HBG1 & $3-6$ \\
\hline$-202 C>G$ & $H B G 2$ & $\begin{array}{c}\text { 15-20; ZBTB7A binding site; associated with } \mathrm{HbS} \\
\text { trait }\end{array}$ \\
\hline$-202 \mathrm{C}>\mathrm{T}$ & $H B G 1$ & 3 in sickle cell anemia: ZBTB7A binding site; \\
\hline$-202+C$ & HBG2 & 25 in heterozygotes, 50 in homozygotes \\
\hline$-198 \mathrm{~T}>\mathrm{C}$ & HBG1 & 4-12: ZBTB7A binding site \\
\hline$-196 \mathrm{C}>\mathrm{T}$ & $H B G 1$ & 15-21: ZBTB7A binding site; 40 with $\beta$ thalassemia \\
\hline$-197 \mathrm{C}>\mathrm{T}$ & $H B G 1$ & 6: ZBTB7A binding site \\
\hline$-195 \mathrm{C}>\mathrm{G}$ & HBG1 & 5: ZBTB7A binding site \\
\hline$-175 \mathrm{~T}>\mathrm{C}$ & $H B G 1$ & 17-38: TAL1 binding site. 40 in $\mathrm{HbS}$ trait \\
\hline$-175 \mathrm{~T}>\mathrm{C}$ & HBG2 & 28: TAL1 binding site \\
\hline$-161 \mathrm{G}>\mathrm{A}$ & HBG2 & $1-2$ \\
\hline$-158 \mathrm{C}>\mathrm{T}^{1}$ & $H B G 2$ & $\begin{array}{l}<1 \text { : higher levels under stress erythropoiesis; } \\
\text { disruption of binding site increases HbS. The } \\
\text { transcription factor binding here is uncharacterized. }\end{array}$ \\
\hline$-158 \mathrm{C}>\mathrm{T}$ & $H B G 1$ & 3-5: occurs in cis to the $-158 \mathrm{C}>\mathrm{T}$ in $\mathrm{HBG} 2$ \\
\hline$-117 \mathrm{G}>\mathrm{A}$ & $H B G 1$ & 9: BCL11A binding site \\
\hline$-114 \mathrm{C}>\mathrm{T}$ & HBG2 & 11-14: BCL11A binding site \\
\hline$-114 \mathrm{C}>\mathrm{T}$ & $H B G 1$ & 3-6: BCL11A binding site \\
\hline$-114 \mathrm{C}>\mathrm{G}$ & $H B G 2$ & 9: BCL11A binding site \\
\hline$-114 \mathrm{C}>\mathrm{G}$ & HBG1 & 38 in $\mathrm{HbS}$ heterozygote: BCL11A binding site \\
\hline-13 bp $(-114 /-102)$ & $H B G 1$ & 30: BCL11A binding site; associated with $\mathrm{HbS}$ \\
\hline$-113 \mathrm{~A}>\mathrm{G}$ & $H B G 1$ & 7: creates new GATA binding site \\
\hline$-110 \mathrm{~A}>\mathrm{C}$ & HBG2 & $1: 3$ in $\beta$ thalassemia trait \\
\hline
\end{tabular}

${ }^{1}$ Only the -158 HBG2 C > T variant, rs7482144, is polymorphic. (www.globon.cse.psu.edu/) [29,35,36].

Point mutations in transcription factor binding sites in patients with sickle cell anemia or other hemoglobin disorders are rarely detected, especially when $\mathrm{HbF}$ levels are not high enough to prompt further studies. The phenotype of sickle cell anemia with $\gamma$-globin gene promotor mutations resembles that of $\mathrm{HbS}$-deletion $\mathrm{HPFH}$ if $\mathrm{HbF}$ levels are $\sim 30 \%$ and distributed pancellularly. Nevertheless, the number of cases reported is far fewer than reports of HbS-deletion HPFH.

\section{Quantitative Trait Loci Modulating HbF Production}

Most patients with $\mathrm{HbS}$ and very high levels of $\mathrm{HbF}$ do not have any of the aforementioned HPFH mutations and continue to have hemolytic anemia and sickle vasoocclusive complications, albeit perhaps at a lower rate. This is likely to be a result of the extreme heterogeneity of $\mathrm{HbF}$ distribution amongst F-cells, where despite the high total $\mathrm{HbF}$ level, a clinically important fraction of erythrocytes contain insufficient $\mathrm{HbF}$ to protect them from $\mathrm{HbS}$ polymer inflicted damage [4]. Perhaps interpatient variability in erythropoietic stress accounts for very high $\mathrm{HbF}$ levels in some individuals lacking HPFH mutations. Studies in primates suggested wide inter-animal differences in the $\mathrm{HbF}$ response to stress erythropoiesis [37].

Recent reviews have summarized the molecular basis of $\mathrm{HbF}$ repression in the fetus and the ensuing switch to adult hemoglobins [38-40]. Higher than expected levels of $\mathrm{HbF}$ in sickle cell anemia can be a result of polymorphisms of the major QTL that modulate $\mathrm{HbF}$ gene expression. Three QTL, $B C L 11 A, M Y B$ and HBG2, are known to be associated with $\mathrm{HbF}$ levels accounting for 10 to $50 \%$ of $\mathrm{HbF}$ variance [41]. The minor allele frequencies of the sentinel variants, or single nucleotide polymorphisms (SNPs) of these QTL, in sickle cell anemia varies by geographic origin. In sickle cell anemia, the sentinel SNP of the HBG2 QTL, rs7482144 is present only in the Senegal haplotype of the HbS gene common 
in patients from West Central Africa and in patients who have the Arab-Indian HbS haplotype and ancestry from Eastern Saudi Arabia or India.

From the records of the Hemoglobin Diagnostic Reference Laboratory (www.bu.edu/sicklecell), Akinsheye and her coworkers culled samples from 20 African Americans who were homozygous for the $\mathrm{HbS}$ gene with $\mathrm{HbF}$ of $17.2 \pm 4.8 \mathrm{~g} / \mathrm{dL}$, were more than five years old, had $\mathrm{MCV}<100 \mathrm{fL}$ and who had neither gene deletion $\mathrm{HPFH}$ nor point mutations in $\mathrm{HbF}$ gene promoters. These individuals were compared with 30 similar patients with $\mathrm{HbF}$ of $5.0 \pm 2.5 \%$ [34]. Minor alleles of the sentinel SNPs of BCL11A (rs766432) and MYB (rs9399137) were more frequent in the high HbF group and accounted for $20 \%$ of $\mathrm{HbF}$ variance. The number of minor alleles present (NOMAP score) [42] in the high $\mathrm{HbF}$ patients was significantly greater than in the low $\mathrm{HbF}$ controls. These results were replicated when $56 \mathrm{HbS}$ homozygotes with $\mathrm{HbF}$ of $20.7 \pm 8.2 \%$, who were followed in the Cooperative Study of Sickle Cell Disease (CSSCD), were compared with 489 individuals with $\mathrm{HbF}$ of $3.1 \pm 1.5 \%$. The minor allele frequencies of $B C L 11 A, M Y B$ and $H B G 2$ were all significantly higher in the high $\mathrm{HbF}$ group. Primate studies have suggested that erythropoietic stress increases $\gamma$-globin gene expression when BCL11A was downregulated using CRISPR-Cas9 editing of its erythroid enhancer [43].

\section{Therapeutic Targeting HbF QTL and Mutations}

Understanding the mechanisms of some instances of unusually high $\mathrm{HbF}$ in sickle cell anemia and knowing the clinical benefits associated with high pancellular levels of $\mathrm{HbF}$ is being exploited for possible therapeutic benefit.

The $\sim 13 \mathrm{~kb}$ Sicilian HPFH deletion was created in CD $34^{+}$hematopoietic progenitor cells using CRISPR-Cas9 in an attempt to reproduce the high $\mathrm{HbF}$ associated with this deletion [44]. In erythroid colonies derived from cells homozygous for this deletion, there was no $H B B$ mRNA; cells heterozygous for the deletion synthesized half as much $H B B$ mRNA as control cells. The ratio of $H B G / H B B+H B G$ mRNA was $\sim 0.1$ in controls, $\sim 0.3$ in deletion heterozygotes and 1 in deletion homozygotes. Based on these studies, to be applicable therapeutically, only cells heterozygous for the deletion are needed.

CRISPR-Cas9 was used to mutate the $13 \mathrm{bp}$ sequence in the promoters of $H B G 2$ and HBG1 that is associated with $\mathrm{HPFH}$ (Table 2). Edited progenitors derived from HUDEP-2 cells expressing $\mathrm{HbA}$ gave rise to $\sim 50 \%$ F-cells and increased the $H B G / H B B+H B G$ mRNA ratio; $58 \%$ of the erythroid cells derived from edited $\mathrm{CD} 34^{+}$progenitors were F-cells; $\mathrm{HbF}$ was $\sim 20 \%$. Erythrocytes derived from sickle CD $34^{+}$progenitors were $90 \%$ F-cells and protected from hypoxia-induced sickling $[30,45]$.

CRISPR-Cas9 editing in both HUDEP-2 cells and CD34+ progenitors from patients with sickle cell anemia generated small deletions disrupting the binding motifs for: ZBTB7A 195-197 bp upstream of both HBG2 and HBG1; the BCL11A binding motif 115 bp upstream of both HBG2 and HBG1; and the QTL 158 bp upstream of $H B G 2$. These induced mutations mimicked HPFH mutations (Table 2). The editing efficiency was $>80 \%$. Editing the ZBTB7A binding site in patient CD34 ${ }^{+}$cells resulted in: $\gamma$-globin transcripts forming $\sim 50 \%$ of all non- $\alpha$ transcripts; $\sim 80$ F-cells; $\mathrm{HbF}$ comprising $\sim 50 \%$ of hemoglobin tetramers; and $\sim 70$ of cells protected from hypoxia-induced sickling in vitro [30].

\section{Conclusions}

Unusually high $\mathrm{HbF}$ levels of $20.7 \pm 8.2 \%$ were present in $\sim 5 \%$ of untreated patients with sickle cell anemia. When compared with patients with more customary HbF levels $(3.1 \pm 1.5 \%)$ their hemoglobin concentrations were higher $(9.6 \pm 1.5$ vs. $8.1 \pm 1.1 \mathrm{~g} / \mathrm{dL})$ and they were younger $(15.2 \pm 10.9 \mathrm{vs}$. $19.1 \pm 10.8)$, although well beyond the age that $\mathrm{HbF}$ stabilizes in African Americans with sickle cell anemia [2,34]. Rarely are these unusually high $\mathrm{HbF}$ levels a result of mutations in the HBB gene cluster; perhaps more often they are caused by partial reversal of $\mathrm{HbF}$ gene repression by the minor alleles of the three known HbF-associated QTL. Nevertheless, QTL associated with $\mathrm{HbF}$ appear to account for less than half of $\mathrm{HbF}$ variance [46] and most instances of very high $\mathrm{HbF}$ remain unexplained. These instances could be a result of rare alleles of still uncharacterized $\mathrm{HbF}$ repressors or in genes, such as $K L F 1$, that activate BCL11A, ZBTB7A and HBB. Variations in epigenetic HbF regulators, the intensity of 
stress erythropoiesis and cell stress signaling and a possible $\mathrm{X}$-linked regulatory locus require further study [47-52]. With the widespread use of hydroxyurea to induce increased levels of $\mathrm{HbF}$, it could be difficult to acquire a sufficient number of untreated cases to study. In addition to careful longitudinal clinical and hematologic examination, extensive genomic and transcriptomic analysis might help define previously uncharacterized $\mathrm{HbF}$ modulators.

Funding: This research received no external funding.

Conflicts of Interest: The author declares no conflict of interest.

\section{Abbreviations}

Sickle cell anemia

HPFH

Mutation ${ }^{1}$

Polymorphism ${ }^{1}$

SNP

FACS

HBB, HBD, HBG2, HBG1

QTL

LCR

$\mathrm{CD}^{3} 4^{+}$

$\mathrm{HbF}$

F-cell

$\mathrm{HbS}$

bp

${ }^{1}$ A mutation might reach polymorphic frequencies if it confers a selective advantage, such as the HbS gene where malaria is endemic.
Base pairs

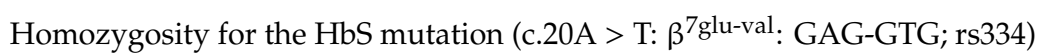

Hereditary persistence of fetal hemoglobin

A rare genetic variant

A genetic variant present in $\sim 1 \%$ of a population

Single nucleotide polymorphism

Fluorescence-activated cell sorting

$\beta-, \delta-,{ }_{\gamma-,}{ }^{A} \gamma$-globin genes

Quantitative trait locus

Locus control region

Hematopoietic stem and progenitor cells

Fetal hemoglobin $\left(\alpha_{2} \gamma_{2}\right)$

Red cells containing enough $\mathrm{HbF}$ to be detectable by FACS, usually $\sim 6 \mathrm{pg}$

Sickle hemoglobin $\left(\alpha_{2} \beta^{S}{ }_{2}\right)$

\section{References}

1. Nagel, R.L.; Steinberg, M.H. Hemoglobins of the embryo and fetus and minor hemoglobins of adults. In Disorders of Hemoglobin: Genetics, Pathophysiology and Clinical Management, 1st ed.; Chapter 10; Steinberg, M.H., Forget, B.G., Higgs, D.R., Nagel, R.L., Eds.; Cambridge University Press: Cambridge, UK, 2001.

2. Solovieff, N.; Milton, J.N.; Hartley, S.W.; Sherva, R.; Sebastiani, P.; Dworkis, D.A.; Klings, E.S.; Farrer, L.A.; Garrett, M.E.; Ashley-Koch, A.; et al. Fetal hemoglobin in sickle cell anemia: Genome-wide association studies suggest a regulatory region in the 5' olfactory receptor gene cluster. Blood 2010, 115, 1815-1822. [CrossRef]

3. Ngo, D.; Bae, H.; Steinberg, M.H.; Sebastiani, P.; Solovieff, N.; Baldwin, C.T.; Melista, E.; Safaya, S.; Farrer, L.A.; Al-Suliman, A.M.; et al. Fetal hemoglobin in sickle cell anemia: Genetic studies of the Arab-Indian haplotype. Blood Cells Mol. Dis. 2013, 51, 22-26. [CrossRef] [PubMed]

4. Steinberg, M.H.; Chui, D.H.; Dover, G.J.; Sebastiani, P.; Alsultan, A. Fetal hemoglobin in sickle cell anemia: A glass half full? Blood 2014, 123, 481-495. [CrossRef] [PubMed]

5. Al-Ali, A.K.; Alsulaiman, A.; Alzahrani, A.J.; Obeid, O.T.; Vatte, C.B.; Cyrus, C.; Alnafie, A.N.; Alali, R.A.; Alfarhan, M.; Mozeleski, B.; et al. Prevalence and diversity of haplotypes of sickle cell disease in the Eastern Province of Saudi Arabia. Hemoglobin 2020, 1-4. [CrossRef] [PubMed]

6. Bauer, D.E.; Kamran, S.C.; Orkin, S.H. Fetal hemoglobin in sickle cell anemia. Blood 2011, 118, $19-27$.

7. Bauer, D.E.; Kamran, S.C.; Orkin, S.H. Reawakening fetal hemoglobin: Prospects for new therapies for the $\beta$-globin disorders. Blood 2012, 120, 2945-2953. [CrossRef] [PubMed]

8. Lettre, G.; Bauer, D.E. Fetal haemoglobin in sickle-cell disease: From genetic epidemiology to new therapeutic strategies. Lancet 2016, 387, 2554-2564. [CrossRef]

9. Williams, T.N.; Thein, S.L. Sickle cell anemia and its phenotypes. Annu. Rev. Genomics Hum. Genet. 2018, 19, 113-147. [CrossRef] 
10. Paikari, A.; Sheehan, V.A. Fetal haemoglobin induction in sickle cell disease. Br. J. Haematol. 2018, 180, 189-200. [CrossRef]

11. Steinberg, M.H.; Thein, S.L. Fetal hemoglobin (hemoglobin F) in health and disease. UpToDate 2020. Available online: https://www.uptodate.com/contents/fetal-hemoglobin-hemoglobin-f-in-healthand-disease (accessed on 3 November 2020).

12. Jacob, G.F.; Raper, A.B. Hereditary persistence of foetal haemoglobin production, and its interactions with sickle-cell trait. Br. J. Haematol. 1958, 4, 138-149. [CrossRef]

13. Wood, W.G. Hereditary persistence of fetal hemoglobin and $\delta \beta$ thalassemia. In Disorders of Hemoglobin: Genetics, Pathophysiology and Clinical Management, 1st ed.; Chapter 15; Steinberg, M.H., Forget, B.G., Higgs, D.R., Nagel, R.L., Eds.; Cambridge University Press: Cambridge, UK, 2001.

14. Girton, J.R.; Johansen, K.M. Chromatin structure and the regulation of gene expression: The lessons of PEV in Drosophila. Adv. Genet. 2008, 61, 1-43. [PubMed]

15. Bradley, T.B., Jr.; Brawner, J.N.; Conley, C.L. Further observations on an inherited anomaly characterized by persistence of fetal hemoglobin. Bull. Johns Hopkins Hosp. 1961, 108, 242-257.

16. Conley, C.L.; Weatherall, D.J.; Richardson, S.N.; Shepard, M.K.; Charache, S. Hereditary persistence of fetal hemoglobin: A study of 79 affected persons in 15 Negro families in Baltimore. Blood 1963, 21, $261-281$. [CrossRef] [PubMed]

17. Serjeant, G.R.; Serjeant, B.E.; Forbes, M.; Haye, R.J.; Higgs, D.R.; Lehmann, H. Haemoglobin gene frequencies in the Jamaican population: A study of 100,000 newborns. Br. J. HaernatoI. 1986, 64, 253-262. [CrossRef]

18. Natta, C.L.; Niazi, G.A.; Ford, S.; Bank, A. Balanced globin chain synthesis in hereditary persistence of fetal hemoglobin. J. Clin. Investig. 1974, 54, 433-438. [CrossRef] [PubMed]

19. Ngo, D.A.; Aygun, B.; Akinsheye, I.; Hankins, J.S.; Bhan, I.; Luo, H.Y.; Steinberg, M.H.; Chui, D.H. Fetal haemoglobin levels and haematological characteristics of compound heterozygotes for haemoglobin $S$ and deletional hereditary persistence of fetal haemoglobin. Br. J. Haematol. 2012, 156, 259-264. [CrossRef]

20. Talbot, J.F.; Bird, A.C.; Serjeant, G.R. Retinal changes in sickle cell/hereditary persistence of fetal haemoglobin syndrome. Br. J. Ophthalmol. 1983, 67, 777-778. [CrossRef]

21. Tolu, S.S.; Reyes-Gil, M.; Ogu, U.O.; Thomas, M.; Bouhassira, E.E.; Minniti, C.P. Hemoglobin F mitigation of sickle cell complications decreases with aging. Am. J. Hematol. 2020, 95, E122-E125. [CrossRef]

22. Kulozik, A.E.; Kar, B.C.; Satapathy, R.K.; Serjeant, B.E.; Serjeant, G.R.; Weatherall, D.J. Fetal hemoglobin levels and $\beta S$ globin haplotypes in an Indian population with sickle cell disease. Blood 1987, 69, 1742-1746. [CrossRef]

23. Pandey, H.; Singh, K.; Ranjan, R.; Pandey, S.K.; Sharma, A.; Kishor, K.; Seth, T.; Mahapatra, M.; Saxena, R. Clinical variability and molecular characterization of $\mathrm{HbS} / \mathrm{G} \gamma(\mathrm{A} \gamma \delta \beta) 0$-thal and $\mathrm{HbS} / \mathrm{HPFH}$ in Indian sickle cell disease patients: AIIMS experience. Hematology 2019, 24, 349-352. [CrossRef]

24. Belisário, A.R.; Sales, R.R.; Silva, C.M.; Velloso-Rodrigues, C.; Viana, M.B. The natural history of $\mathrm{Hb}$ $\mathrm{S} /$ hereditary persistence of fetal hemoglobin in 13 children from the State of Minas Gerais, Brazil. Hemoglobin 2016, 40, 215-219. [CrossRef] [PubMed]

25. Whyte, D.; Forget, B.; Chui, D.H.; Luo, H.Y.; Pashankar, F. Massive splenic infarction in an adolescent with hemoglobin S-HPFH. Pediatr. Blood Cancer 2013, 60, E49-E51. [CrossRef] [PubMed]

26. Murray, N.; Serjeant, B.E.; Serjeant, G.R. Sickle cell-hereditary persistence of fetal haemoglobin and its differentiation from other sickle cell syndromes. Br. J. Haematol. 1988, 69, 89-92. [CrossRef] [PubMed]

27. Milner, P.F.; Leibfarth, J.D.; Ford, J.; Barton, B.P.; Grenett, H.E.; Garver, F.A. Increased HbF in sickle cell anemia is determined by a factor linked to the beta $S$ gene from one parent. Blood 1984, 63, 64-72. [CrossRef]

28. Liu, N.; Hargreaves, V.V.; Zhu, Q.; Kurland, J.V.; Hong, J.; Kim, W.; Sher, F.; Macias-Trevino, C.; Rogers, J.M.; Kurita, R.; et al. Direct promoter repression by BCL11A controls the fetal to adult hemoglobin switch. Cell 2018, 173, 430-442. [CrossRef]

29. Martyn, G.E.; Wienert, B.; Yang, L.; Shah, M.; Norton, L.J.; Burdach, J.; Kurita, R.; Nakamura, Y.; Pearson, R.C.; Funnell, A.P.; et al. Natural regulatory mutations elevate the fetal globin gene via disruption of BCL11A or ZBTB7A binding. Nat. Genet. 2018, 50, 498-503. [CrossRef]

30. Weber, L.; Frati, G.; Felix, T.; Hardouin, G.; Casini, A.; Wollenschlaeger, C.; Meneghini, V.; Masson, C.; De Cian, A.; Chalumeau, A.; et al. Editing a $\gamma$-globin repressor binding site restores fetal hemoglobin synthesis and corrects the sickle cell disease phenotype. Sci. Adv. 2020,6, eaay9392. [CrossRef] 
31. Shaikho, E.M.; Farrell, J.J.; Chui, D.H.K.; Sebastiani, P.; Steinberg, M.H. Cis- and trans-acting expression quantitative trait loci differentially regulate gamma-globin gene expression. BioRxiv 2018, 304899. [CrossRef]

32. Coleman, M.B.; Adams, J.G., III; Steinberg, M.H.; Plonczynski, M.W.; Harrell, A.H.; Castro, O.; Winter, W.P. ${ }^{\mathrm{G}} \gamma{ }^{\mathrm{A}} \gamma\left(\beta^{+}\right)$Hereditary persistence of fetal hemoglobin: The ${ }^{\mathrm{G}} \gamma-158 \mathrm{C}-\mathrm{T}$ mutation in cis to the -175 T-C mutation of the ${ }^{\mathrm{A}} \gamma$-globin gene results in increased ${ }^{\mathrm{G}} \gamma$ globin gene synthesis. Am. J. Hematol. 1993, 42, 186-190.

33. Akinbami, A.O.; Campbell, A.D.; Han, Z.J.; Luo, H.Y.; Chui, D.H.; Steinberg, M.H. Hereditary persistence of fetal hemoglobin caused by single nucleotide promoter mutations in sickle cell trait and $\mathrm{Hb}$ SC disease. Hemoglobin 2016, 40, 64-65. [CrossRef]

34. Akinsheye, I.; Solovieff, N.; Ngo, D.; Malek, A.; Sebastiani, P.; Steinberg, M.H.; Chui, D.H. Fetal hemoglobin in sickle cell anemia: Molecular characterization of the unusually high fetal hemoglobin phenotype in African Americans. Am. J. Hematol. 2012, 87, 217-219. [CrossRef] [PubMed]

35. Amato, A.; Cappabianca, M.P.; Perri, M.; Zaghis, I.; Grisanti, P.; Ponzini, D.; Di Biagio, P. Interpreting elevated fetal hemoglobin in pathology and health at the basic laboratory level: New and known $\gamma$ - gene mutations associated with hereditary persistence of fetal hemoglobin. Int. J. Lab. Hematol. 2014, 36, 13-19. [CrossRef] [PubMed]

36. Chen, Z.; Luo, H.Y.; Basran, R.K.; Hsu, T.H.; Mang, D.W.; Nuntakarn, L.; Rosenfield, C.G.; Patrinos, G.P.; Hardison, R.C.; Steinberg, M.H.; et al. A T-to-G transversion at nucleotide -567 upstream of HBG2 in a GATA-1 binding motif is associated with elevated hemoglobin F. Mol. Cell Biol. 2008, 28, 4386-4393. [CrossRef] [PubMed]

37. DeSimone, J.; Biel, S.I.; Heller, P. Stimulation of fetal hemoglobin synthesis in baboons by hemolysis hypoxia. Proc. Natl. Acad. Sci. USA 1978, 75, 2937-2940. [CrossRef] [PubMed]

38. Vinjamur, D.S.; Bauer, D.E.; Orkin, S.H. Recent progress in understanding and manipulating haemoglobin switching for the haemoglobinopathies. Br. J. Haematol. 2018, 180, 630-643. [CrossRef]

39. Wienert, B.; Martyn, G.E.; Funnell, A.P.W.; Quinlan, K.G.R.; Crossley, M. Wake-up sleepy gene: Reactivating fetal globin for beta-hemoglobinopathies. Trends Genet. 2018, 34, 927-940. [CrossRef]

40. Orkin, S.H.; Bauer, D.E. Emerging genetic therapy for sickle cell disease. Ann. Rev. Med. 2019, 70, $257-271$. [CrossRef]

41. Gardner, K.; Fulford, T.; Silver, N.; Rooks, H.; Angelis, N.; Allman, M.; Nkya, S.; Makani, J.; Howard, J.; Kesse-Adu, R.; et al. g(HbF): A genetic model of fetal hemoglobin in sickle cell disease. Blood Adv. 2018, 2, 235-239. [CrossRef]

42. Galanello, R.; Sanna, S.; Perseu, L.; Sollaino, M.C.; Satta, S.; Lai, M.E.; Barella, S.; Uda, M.; Usala, G.; Abecasis, G.R.; et al. Amelioration of Sardinian $\beta 0$ thalassemia by genetic modifiers. Blood 2009, 114, 3935-3937. [CrossRef]

43. Demirci, S.; Zeng, J.; Wu, Y.; Uchida, N.; Shen, A.H.; Pellin, D.; Gamer, J.; Yapundich, M.; Drysdale, C.; Bonanno, J.; et al. BCL11A enhancer edited hematopoietic stem cells persist in rhesus monkeys without toxicity. J. Clin. Investig. 2020, 8, 140189. [CrossRef]

44. Ye, L.; Wang, J.; Tan, Y.; Beyer, A.I.; Xie, F.; Muench, M.O.; Kan, Y.W. Genome editing using CRISPR-Cas9 to create the HPFH genotype in HSPCs: An approach for treating sickle cell disease and $\beta$-thalassemia. Proc. Natl. Acad. Sci. USA 2016, 113, 10661-10665. [CrossRef] [PubMed]

45. Traxler, E.A.; Yao, Y.; Wang, Y.D.; Woodard, K.J.; Kurita, R.; Nakamura, Y.; Hughes, J.R.; Hardison, R.C.; Blobel, G.A.; Li, C.; et al. A genome-editing strategy to treat $\beta$-hemoglobinopathies that recapitulates a mutation associated with a benign genetic condition. Nat. Med. 2016, 22, 987-990. [CrossRef] [PubMed]

46. Bae, H.T.; Baldwin, C.T.; Sebastiani, P.; Telen, M.J.; Ashley-Koch, A.; Garrett, M.; Hooper, W.C.; Bean, C.J.; Debaun, M.R.; Arking, D.E.; et al. Meta-analysis of 2040 sickle cell anemia patients: BCL11A and HBS1L-MYB are the major modifiers of $\mathrm{HbF}$ in African Americans. Blood 2012, 120, 1961-1962. [CrossRef] [PubMed]

47. DeSimone, J.; Biel, M.; Heller, P. Maintenance of fetal hemoglobin (HbF) elevations in the baboon by prolonged erythropoietic stress. Blood 1982, 60, 519-523. [CrossRef] [PubMed]

48. Stamatoyannopoulos, G.; Veith, R.; Galanello, R.; Papayannopoulou, T. Hb F production in stressed erythropoiesis: Observations and kinetic models. Ann. N. Y. Acad. Sci. 1985, 445, 188-197. [CrossRef]

49. Miyoshi, K.; Kaneto, Y.; Kawai, H.; Ohchi, H.; Niki, S.; Hasegawa, K.; Shirakami, A.; Yamano, T. X-linked dominant control of F-cells in normal adult life: Characterization of the Swiss type as hereditary persistence of fetal hemoglobin regulated dominantly by gene(s) on X chromosome. Blood 1988, 72, 1854-1860. [CrossRef] 
50. Mabaera, R.; West, R.J.; Conine, S.J.; Macari, E.R.; Boyd, C.D.; Engman, C.A.; Lowrey, C.H. A cell stress signaling model of fetal hemoglobin induction: What doesn't kill red blood cells may make them stronger. Exp. Hematol. 2008, 36, 1057-1072. [CrossRef]

51. Ginder, G.D. Epigenetic regulation of fetal globin gene expression in adult erythroid cells. Transl. Res. 2015, 165, 115-125. [CrossRef]

52. Renneville, A.; Van Galen, P.; Canver, M.C.; McConkey, M.; Krill-Burger, J.M.; Dorfman, D.M.; Holson, E.B.; Bernstein, B.E.; Orkin, S.H.; Bauer, D.E.; et al. EHMT1 and EHMT2 inhibition induces fetal hemoglobin expression. Blood 2015, 126, 1930-1939. [CrossRef]

Publisher's Note: MDPI stays neutral with regard to jurisdictional claims in published maps and institutional affiliations.

(C) 2020 by the author. Licensee MDPI, Basel, Switzerland. This article is an open access article distributed under the terms and conditions of the Creative Commons Attribution (CC BY) license (http://creativecommons.org/licenses/by/4.0/). 